\title{
Analisis Kehilangan Kadar Aspal Buton untuk Campuran BERASPAL Laston Lapis Antara (AC-BC)
}

\author{
Mardiansah ${ }^{1}$, Ir. Virgo Trisep Haris, M.T. ${ }^{2}$, Fadrizal Lubis. S.T., M.T. ${ }^{3}$ \\ Program Studi Teknik Sipil, Fakultas Teknik, Universitas Lancang Kuning \\ Jl. Yos Sudarso km. 8 Rumbai, Pekanbaru, Telp. (0761) 52324 \\ Email: mardiansah86@ymail.com,Virgo@unilak.ac.id, Fadrizal@unilak.ac.id
}

\begin{abstract}
ABSTRAK
MARDIANSAH. Analisis Kehilangan Kadar Aspal Buton Untuk Campuran Beraspal Laston Lapis Antara (AC-BC). Dibimbing oleh VIRGO TRISEP HARIS dan FADRIZAL LUBIS.

Indonesia merupakan salah satu negara yang memiliki deposit aspal alam (aspal buton) yang terbesar didunia. Ironisnya sebagian besar kebutuhan aspal dalam negeri masih harus selalu diimpor dari luar negeri. Pada saat ini banyak upayaupaya yang dilakukan pemerintah untuk memaksimalkan pemakaian aspal buton untuk menggantikan aspal minyak yang diimpor dari luar. Berpedoman kepada Spesifikasi Umum 2010 Revisi 3 (tiga) telah diisyaratkan bahwa toleransi kadar aspal pada campuran beraspal adalah $\pm 0,3 \%$ dari berat total campuran. Mengenai pengendalian mutu dan pemeriksaan dilapangan, campuran beraspal tersebut diisyaratkan menggunakan metode ekstraksi. Penelitian ini bertujuan untuk mengetahui nilai kehilangan kadar aspal buton terhadap campuran laston lapis antara (AC-BC). Sampel yang digunakan diambil dari campuran aspal panas yang telah diproduksi oleh asphalt mixing plant (AMP), pada alat pengangkut dump truck, pada alat penghampar Asphalt Finisher, dan uji inti (core). Berdasarkan hasil penelitian, nilai rata-rata kadar aspal dari Asphalt Mixing Plant, Dump Truck, Asphalt Finisher dan Uji Inti (core) adalah 5,6\%, 5,59\%, $5,58 \%, 5,49 \%$. Dengan deviasi rata-rata sebesar 0,03\% dari kadar Job Mix Formula 5,6\%.
\end{abstract}

Kata Kunci: Aspal Buton, Laston Lapis Antara, Ekstraksi Aspal, AC-BC

\begin{abstract}
MARDIANSAH. An Analysis of Buton Asphalt Content Loss for Laston Lapis Antara (AC-BC) Mixture. Supervised by VIRGO TRISEP HARIS and FADRIZAL LUBIS.

Indonesia is one of the countries that has the largest deposits of natural asphalt (buton asphalt) in the world. Ironically, most of the domestic asphalt needs must always be imported from abroad. Nowadays, there are many efforts made by the government to maximize the use of buton asphalt to replace oil asphalt imported from outside. Guided by the General Specification on 2010 of Revision 3 (three), it has been suggested that the tolerance of the asphalt content in the asphalt mixture is $\pm 0,3 \%$ of the total weight of the mixture. Regarding quality control and inspection in the field, the asphalt mixture is indicated using the extraction method. This study aims to determine the value of the Buton Asphalt Content Loss for Laston Lapis Antara (AC-BC) Mixture. The sample used was taken from a mixture of hot asphalt that had been produced by asphalt mixing plant (AMP), on the Dump Truck conveyor, on the Asphalt Finisher spreader, and the Core Test (core). Based on the results of the study, the average value of asphalt content from the Asphalt Mixing Plant, Dump Truck, Asphalt Finisher and Core Test (Core) was 5,6\%, 5,59\%, 5,58\%, 5,49\% with an average deviation of 0,03\% from the level of the Job Mix Formula 5,6\%.
\end{abstract}

Keywords: Asphalt Buton, Laston Lapis Antara (AC-BC), Asphalt Extraction

\section{PENDAHULUAN}

Jalan merupakan infrastuktur yang berfungsi sebagai penghubung antara kawasan satu ke kawasan lainnya yang digunakan oleh masyarakat umum, serta dilewati oleh berbagai macam kendaraan bermotor. Sebagai infrastruktur yang digunakan oleh masyarakat umum, kualitas jalan diharapkan dapat memberikan kenyamanan bagi penggunanya. Oleh karena itu diperlukan suatu struktur perkerasan jalan yang konstruksinya baik serta jauh dari kerusakan.

Indonesia merupakan salah satu negara yang memiliki deposit aspal alam yang terbesar didunia.
Ironisnya sebagian besar kebutuhan aspal dalam negeri masih selalu diimpor dari luar negeri berupa aspal minyak. Pada saat ini banyak upaya-upaya yang dilakukan pemerintah untuk memaksimalkan pemakaian aspal buton untuk menggantikan aspal minyak yang diimpor dari luar. Campuran beraspal dengan bahan dasar aspal buton telah banyak dilakukan oleh pihak kontraktor pelaksana dalam pekerjaan jalan raya.

Berpedoman kepada Spesifikasi Umum 2010 Revisi 3 (tiga) telah diisyaratkan bahwa toleransi kadar aspal pada campuran beraspal adalah $\pm 0,3 \%$ dari berat total campuran. Hal ini mengindikasi bahwa kadar aspal sangat berpengaruh terhadap pelayanan lapis perkerasan 
jalan. Mengenai pengendalian mutu dan pemeriksaan dilapangan untuk campuran beraspal tersebut diisyaratkan menggunakan metode ekstraksi. Kekurangan kadar aspal akan berdampak terhadap kualitas jalan. Banyak faktor yang dapat menimbulkan pengurangan kadar aspal dilapangan. Kemungkinan pengurangan tersebut terjadi pada saat proses pencampuran dan pendistribusian aspal dan sampai kelokasi pekerjaan.

Berdasarkan keterangan diatas uji ekstraksi aspal mutlak dilakukan. Hasil ekstraksi tersebut nantinya akan di bandingkan dengan Job Mix Design, maka dari itu dilakukan "Analisis Kehilangan Kadar Aspal Buton Untuk Campuran Beraspal Laston Lapis Antara (ACBC)" terhadap proses pelaksanaan yang dimulai dari instalasi pencampur aspal Asphalt Mixing Plant (AMP), pengangkutan Dump Truck, Penghamparan Asphalt Finisher, setelah pemadatan uji inti (core).

\section{TINJAUAN PUSTAKA}

\section{Bahan dan Alat}

Aspal atau bitumen merupakan material yang berwarna hitam kecoklatan yang bersifat viskoelastis sehingga akan melunak dan mencair bila mendapat cukup pemanasan dan sebaliknya. Sifat viskoelastis inilah yang membuat aspal dapat menyelimuti dan menahan agregat tetap pada tempatnya selama proses produksi dan masa pelayananya. Pengerasan aspal dapat terjadi karena oksidasi, penguapan, dan perubahan kimiawi lainya. Menurut Wignall A. (2003) aspal dapat dibagi menjadi 2 (dua), yaitu:

1. Aspal Alam.

2. Aspal Buatan.

Aspal alam dapat berasal dari bantuan pegunungan (rock asphalt) dan danau (lake asphalt). Aspal buatan didapat dari proses destilasi minyak bumi, dengan pemanasan $350^{\circ} \mathrm{C}$ dibawah tekanan atmosfir untuk memisahkan fraksi-fraksi ringan, seperti gasoline (bensin), kerosene (minyak tanah) dan gas oli. Hasil proses destilasi/ penyulingan minyak tanah mentah menghasilkan 3 (tiga) macam aspal Suryadharma $\mathrm{H}$. (2008), yaitu:

1. Aspal keras/panas (asphalt cement, AC).

2. Aspal dingin/cair (cut back asphalt).

3. Aspal emulsi (amulsion asphalt).

\section{Aspal Buton (asbuton)}

Aspal Buton (asbuton) adalah aspal alam yang terkandung dalam deposit batuan yang terdapat dipulau Buton (Sulawesi Tenggara) dan sekitarnya. Dengan jumlah deposit Asbuton mencapai 650 juta ton, menjadikan Indonesia sebagai negara penghasil aspal alam terbesar didunia. Kadar aspal yang terkandung dalam Asbuton bervariasi, antara 10\% - 40\%. Ini merupakan kadar aspal yang cukup besar dibandingkan dengan kadar aspal alam di negara-negara seperti Amerika (12\% - 15\%) dan Perancis $(6 \%-10 \%)$. Namun dengan potensi sumber daya alam (SDA) yang begitu besarnya, Indonesia masih belum bias mencukupi kebutuhan aspal dalam negeri. Ini disebabkan karena Asbuton, sebagai bahan baku pembuat konstruksi jalan, masih belum banyak digunakan. Dari segi mutu, Asbuton dirasa masih kalah bersaing dengan aspal minyak. Kadar aspal Asbuton yang bervariasi, mudah pecah, dan harga lebih mahal menjadi alasan kenapa Asbuton menjadi jarang dipakai. Namun seiring dengan melonjaknya harga aspal minyak sejak 2002 lalu, maka penggunaan Asbuton saat ini dinilai dinilai lebih murah dan efisien. Asbuton juga mempunyai kelebihan yakni titik lembeknya lebih tinggi dari aspal minyak dan ketahanan Asbuton yang cukup tinggi terhadap panas, sehingga membuatnya tidak mudah meleleh. Sesuai dengan keluarnya Peraturan Menteri PU No.35 /2006, saat ini pemerintah juga bertekad untuk menggalakkan pengunaan aspal buton pada pekerjaan perbaikan, pembangunan dan peningkatan jalan diseluruh Provinsi yang ada di Indonesia.

\section{Karakteristik Campuran Aspal Beton}

Karakteristik campuran yang harus dimiliki oleh campuran aspal beton campuran panas adalah sebagai berikut:

\section{Stabilitas}

Stabilitas lapisan perkerasan jalan adalah kemampuan lapisan perkerasan saat menerima beban lalu lintas tanpa terjadi perubahan bentuk tetap seperti gelombang, alur ataupun bleeding. Kebutuhan stabilitas akan setingkat dengan jumlah lalu lintas dan beban kendaraan yang akan memakai jalan tersebut. Dengan demikian stabilitas yang tinggi dapat diperoleh dengan mengusahakan penggunaan:

a. Agregat dengan gradasi yang rapat (dense graded)

b. Agregat dengan permukaan yang kasar.

c. Agregat berbentuk kubus.

d. Aspal dengan penetrasi rendah.

e. Aspal dalam jumlah yang mencukupi untuk ikatan antar butiran.

Agregat yang bergradasi baik atau bergradasi rapat akan memberikan rongga antar butiran agregat (voids in mineral aggregate) yang kecil yang menghasilakn stabilitas yang tinggi, tetapi membutuhkan kadar aspal yang rendah untuk mengikat agregat. Void in mineral Aggregate (VMA) yang kecil mengakibatkan aspal yang menyelimuti agregat terbatas dan menghasilkan film aspal yang tipis. Film aspal yang tipis mudah lepas yang mengakibatkan lapisan tidak kedap air, oksidasi mudah terjadi, dan lapisan perkerasan menjadi rusak. Sementara sebaliknya pemakaian aspal yang banyak mengakibatkan aspal tidak lagi dapat menyelimuti agregat dengan baik karena VMA kecil dan juga menghasilkan rongga antar campuran voids in mix (VIM) yang kecil. Adanya beban lalu lintas yang menambah pemadatan lapisan mengakibatkan lapisan aspal meleleh keluar yang disebut bleeding. 
2. Durabilitas (keawetan/daya tahan)

Durabilitas diperlukan pada lapisan permukaan sehingga lapisan dapat mampu menahan keausan akibat pengaruh cuaca, air dan perubahan suhu ataupun keausan akibat gesekan roda kendaraan. Faktor yang mempengaruhi durabilitas lapisan aspal beton adalah:

a. VIM yang kecil sehingga lapis kedap air dan udara tidak masuk kedalam campuran yang menyebabkan terjadinya oksidasi dan aspal menjadi rapuh (getas).

b. VMA besar sehingga film aspal dapat dibuat tebal. Jika VMA dan VIM kecil serta kadar aspal tinggi makan kemungkinan terjadinya bleeding cukup besar. Untuk mencapai VMA yang besar ini dipergunakan agregat bergradasi senjang.

c. Film (selimut) aspal, film aspal yang tebal dapat menghasilkan lapisan aspal beton yang berdurabilitas tinggi, akan tetapi kemungkinan terjadinya bleeding menjadi besar.

3. Fleksibilitas (kelenturan)

Fleksibilitas pada lapisan perkerasan adalah kemampuan lapisan perkerasan untuk dapat mengikuti deformasi yang terjadi akibat beban lalu lintas berulang tanpa timbulnya retak dan perubahan volume. Untuk mendapatkan fleksibilitas yang tinggi dapat diperoleh dengan:

a. Penggunaan agregat bergradasi senjang sehingga diperoleh VMA yang besar.

b. Penggunaan aspal lunak (aspal dengan penetrasi yang tinggi).

c. Penggunaan aspal yang cukup banyak sehingga diperoleh VIM yang kecil.

4. Skid Resistensi (kekesatan)

Tahanan geser adalah kekesatan yang diberikan oleh perkerasan sehingga kendaraan tidak mengalami slip baik diwaktu hujan (basah) maupun diwaktu kering. Kekesatan dinyatakan dengan koefisien gesek antara permukaan jalan dengan roda kendaraan. Tingginya nilai tahanan geser ini dipengaruhi oleh:

a. Penggunaan agregat dengan permukaan kasar.

b. Penggunaan kadar aspal yang tepat sehingga tidak terjadi bleeding.

c. Penggunaan agregat berbentuk kubus.

d. Penggunaan agregat kasar yang cukup.

5. Fatique Resistance (ketahanan kelelahan)

Ketahanan kelelahan adalah ketahan dari lapis aspal beton dalam menerima beban berulang tanpa terjadinya kelelahan yang berupa alur (rutting) dan retak. Faktor yang mempengaruhi ketahanan terhadap kelelahan adalah:

a. VIM yang tinggi dan kadar aspal yang rendah akan mengakibatkan kelelahan yang lebih cepat.

b. VMA dan kadar aspal yang tinggi mengakibatkan lapis perkerasan menjadi fleksibel.
6. Workability (kemudahan pelaksanaan)

Kemudahan pelaksanaan adalah mudahnya suatu campuran untuk dihampar dan dipadatkan sehingga diperoleh hasil yang memenuhi kepadatan yang diharapkan. Workability ini dipengaruhi oleh:

a. Gradasi agregat. Agregat bergradasi baik lebih mudah dilaksanakan dari pada agregat bergradasi lain.

b. Temperatur campuran yang ikut mempengaruhi kekerasan bahan pengikat yang bersifat termoplastis.

c. Kandungan bahan pengisi (filler) yang tinggi menyebabkan pelaksanaan lebih sulit.

\section{Agregat}

Menurut Sukirman S. (2003), agregat merupakan butir-butir batu pecah, kerikil, pasir atau mineral lain, baik yang berasal dari alam maupun buatan yang berbentuk mineral padat berupa ukuran besar maupun kecil atau fragmen-fragmen. Agregat merupakan komponen utama dari struktur perkerasan perkerasan jalan, yaitu 90\% - 95\% agregat berdasarkan persentase berat, atau 75 - 85\% agregat berdasarkan persentase volume. Dengan demikian kualitas perkerasan jalan ditentukan juga dari sifat agregat dan hasil campuran agregat dengan material lain.

Sifat agregat merupakan salah satu faktor penentu kemampuan perkerasan jalan memikul beban lalu lintas dan daya tahan terhadap cuaca. Yang menentukan kualitas agregat sebagai material perkerasan jalan adalah:

1. Gradasi

2. Kebersihan

3. Kekerasan

4. Ketahanan agregat

5. Bentuk butir

6. Tekstur permukaan

7. Porositas

8. Kemampuan untuk menyerap air

9. Berat jenis

10. Daya kelekatan terhadap aspal

\section{Nilai Keausan Agregat}

Daya tahan agregat merupakan ketahanan agregat terhadap adanya penurunan mutu akibat proses mekanis dan kimiawi. Agregat dapat mengalami degradasi, yaitu perubahan gradasi, akibat pecahnya butir-butir agregat. Kehancuran agregat dapat disebabkan oleh proses mekanis, seperti gaya-gaya yang terjadi selama proses pelaksanaan perkerasan jalan (penimbunan, penghamparan dan pemadatan), pelayanan terhadap beban lalu lintas, dan proses kimiawi, seperti pengaruh kelembaban, kepanasan, dan perubahan suhu sepanjang hari.

\section{Bentuk Dan Tekstur Agregat}


Berdasarkan bentuknya, partikel atau butir agregat dikelompokkan sebagai berbentuk bulat, lonjong, pipih, kubus, tak beraturan atau mempunyai bidang pecahan. Berikut penjelasannya dibawah ini:

1. Agregat berbentuk bulat

Agregat yang ditemui disungai pada umumnya telah mengalami erosi, sehingga berbentuk bulat (rounded) dan licin. Bidang kontak antar agregat berbentuk bulat sangat sempit, hanya berupa titik singgung, sehingga menghasilkan penguncian antar agregat yang tidak baik dan menghasilkan kondisi kepadatan lapisan perkerasan yang kurang baik.

2. Agregat berbentuk kubus

Agregat berbentuk kubus (cubical) pada umunya merupakan agregat hasil pemecahan batu massif atau hasil pemecahan mesin pemecah batu. Bidang kontak agregat ini luas, sehingga mempunyai daya saling mengunci yang baik. Kestabilan yang diperoleh lebih baik dan lebih tahan terhadap depormasi. Agregat ini merupakan agregat yang terbaik untuk dipergunakan sebagai material perkerasan jalan.

3. Agregat berbentuk lonjong

Agregat berbentuk lonjong (elongated) dapat ditemukan disungai atau bekas endapan sungai. Agregat dikatakan lonjong jika ukuran terpanjangnya lebih dari 1,8 kali diameter rata-rata. Indek kelonjongan (elongated index) adalah persentase berat agregat lonjong berat total. Sifat campuran agregat berbentuk lonjong ini hampir sama dengan agregat berbentuk bulat.

4. Agregat berbentuk pipih.

Agregat berbentuk pipih (flacky) merupakan hasil dari produksi dari mesin pemecahbatu, dan biasanya agregat ini memang cenderung pecah dengan bentuk pipih. Agregat pipih yaitu agregat yang ketebalannya lebih tipis dari 0,6 kali diameter ratarata. Indeks kepipihan adalah berat total agregat yang lolos slot dibagi berat total agregat yang tertahan slot pada ukuran nominal tertentu.

\section{Klasifikasi Agregat Campuran Beraspal Panas}

Pembagian agregat berdasarkan ukuran butiran menurut spesifikasi teknis 2010 revisi 3 (tiga) yakni:

1. Agregat Kasar adalah fraksi agregat kasar yang tertahan pada ayakan No. $4(4,75 \mathrm{~mm})$ yang dilakukan secara basah dan harus bersih, keras, awet dan bebas dari lempung atau bahan yang tidak dikehendaki lainnya. Dan fraksi agregat kasar harus dari batu pecah mesin dan disiapkan dalam ukuran nominal sesuai dengan jenis campuran yang direncanakan.

2. Agregat halus adalah fraksi agregat halus dari sumber bahan manapun, harus terdiri dari pasir atau hasil pengayakan batu pecah dan terdiri dari bahan yang lolos ayakan No. 4 (4,75 mm) yang mana Fraksi agregat halus harus ditempatkan terpisah dari agregat kasar.
3. Bahan pengisi (Filler) adalah bahan pengisi yang terdiri dari debu batu kapur atau debu kapur padam, semen atau mineral yang berasal dari Asbuton yang sumbernya disetujui oleh Direksi Pekerjaan. Mineral Asbuton harus mengandung bahan yang lolos ayakan No. 100 (150 micron) tidak kurang dari 95\% terhadap beratnya.

Gradasi agregat gabungan untuk campuran aspal panas, ditunjukkan dalam persen (\%) terhadap berat agregat dan bahan pengisi, harus memenuhi batas-batas yang diberikan dalam tabel 2.6.

Tabel 1. Amplop gradasi agregat gabungan untuk campuran aspal.

\begin{tabular}{|c|c|c|c|}
\hline \multirow{3}{*}{$\begin{array}{c}\text { Ukuran } \\
\text { Ayakan } \\
(\mathrm{mm})\end{array}$} & \multirow{2}{*}{\multicolumn{3}{|c|}{$\begin{array}{c}\% \text { Berat yang lolos terhadap total } \\
\begin{array}{c}\text { aggregat gabungan untuk } \\
\text { campuran aspal }\end{array} \\
\text { Laston }(\mathrm{AC})\end{array}$}} \\
\hline & & & \\
\hline & $\mathrm{WC}$ & $\mathrm{BC}$ & Base \\
\hline 37,5 & - & - & 100 \\
\hline 25 & - & 100 & $90-100$ \\
\hline 19 & 100 & $90-100$ & $76-90$ \\
\hline 12,5 & $90-100$ & $75-90$ & $60-78$ \\
\hline 9,5 & $77-90$ & $66-82$ & $52-71$ \\
\hline 4,75 & $53-69$ & $46-64$ & $35-54$ \\
\hline 2,36 & $33-53$ & $30-49$ & $23-41$ \\
\hline 1,18 & $21-40$ & $18-38$ & $13-30$ \\
\hline 0,600 & $14-30$ & $12-28$ & $10-22$ \\
\hline 0,300 & $9-22$ & $7-20$ & $6-15$ \\
\hline 0,150 & $6-15$ & $5-13$ & $4-10$ \\
\hline 0,075 & $4-9$ & $4-8$ & $3-7$ \\
\hline
\end{tabular}

(Sumber : Spesifikasi Umum 2010 Revisi 3)

Campuran beraspal terdiri dari agregat, bahan pengisi, bahan aditif, dan aspal. Persentase aspal yang aktual ditambahkan kedalam campuran ditentukan berdasarkan percobaan laboratorium dan lapangan sebagaimana tertuang dalam rencana campuran kerja atau Job Mix Formula (JMF) dengan memperhatikan penyerapan agregat yang digunakan. Sebelum diperkenankan untuk menghampar setiap campuran beraspal dalam pekerjaan penyedia jasa harus menguji campuran percobaan di laboratorium dan juga dengan 
penghamparan campuran percobaan yang dibuat $\mathrm{di}$ intstalasi pencampur aspal.

Sebelum semua terlaksana penyedia jasa juga harus memperhatikan beberapa petunjuk teknis yang telah tertuang pada kontrak kerja. Yang mana kontrak kerja merupakan landasan dasar dalam sebuah pekerjaan yang akan disepakati dari awal pekerjaan sampai akhir kegiatan. Semua petunjuk teknis ada didalamnya. Berikut beberapa pengujian yakni dimulai dari meliputi analisa ayakan, berat jenis dan penyerapan air, dan semua jenis pengujian lain sepeti penentuan berat jenis maksimum campuran beraspal (SNI 03-6893-2002), pengujian sifat-sifat marshall (SNI 06-2489-1990) dan kepadatan membal (refusal density) campuran rancangan.

\section{METODE PENELITIAN}

Penelitian ini dilaksanakan dengan menggunakan pengujian di laboratorium dan pengambilan bendal uji di lapangan. Tahapan pelaksanaan penelitian dilakukan meliputi persiapan bahan dan alat. Pengujian kadar aspal buton dari campuran beraspal laston lapis antara (AC-BC) dilakukan dengan metode sentrifus (SNI 03-6894-2002), untuk sampel benda uji di ambil pada asphalt mixing plant (AMP), di dalam Dump Truck (setiba dilapangan), di belakang Asphalt Finisher dan uji inti (core) yang telah dipadatkan. Dari setiap pengambilan benda uji diambil 6 sampel yang mana setiap sampel mempunyai berat \pm 1100 gram.

\section{Bahan dan Alat}

Bahan-bahan yang digunakan dalam penelitian ini adalah sebagai berikut:

1. Sampel campuran beraspal pada asphalt mixing plant (AMP).

2. Sampel campuran beraspal pada dump truck.

3. Sampel campuran beraspal pada belakang asphalt finisher.

4. Sampel setelah pemadatan uji inti (hasil core).

5. Pelarut bensin.

Alat-alat yang digunakan dalam penelitian ini adalah sebagai berikut:

1. Alat ekstraksi sentrifus (mesin ekstaktor)

2. Mesin Core Drill

3. Talam

4. Kuas

5. Kertas Saring

6. Timbangan kapasitas $5 \mathrm{Kg}$

7. Timbangan kapasitas $250 \mathrm{Kg}$

8. Oven dengan alat pengatur suhu

9. Cawan

10. Peralatan kadar air

11. Sekop

12. Karung

13. Sikat kawat
Ektraksi adalah proses pemisahan dua zat atau lebih dengan menggunakan pelarut yang tidak saling mencampur.

Rumus untuk menentukan kadar aspal hasil ekstraksi (SNI 03-6894-2002) adalah sebagai berikut:

$\mathrm{H}=\frac{\mathrm{A}-(\mathrm{E}+\mathrm{D})}{\mathrm{A}} \times 100 \%$

Keterangan :

$\mathrm{H}=$ kadar aspal sampel (\%)

$\mathrm{A}=$ berat sampel sebelum ekstraksi (gram)

$\mathrm{E}=$ berat sampel setelah ekstraksi (gram)

$\mathrm{D}=$ berat masa dari kertas filter (gram)

\section{Cara Analisis}

Kadar aspal buton hasil ekstraksi dari campuran Laston Lapis Antara (AC-BC) yang diambil dari Asphalt Mixing Plant (AMP) dibandingkan dengan kadar aspal yang diambil dari dump truck, dari asphalt finisher dan hasil uji inti (core). Setelah dilakukan pengujian sampel pada setiap pengambilan benda uji dilanjutkan dengan menganalisis penurunan kadar aspal hasil ekstraksi tersebut dan dibandingkan dengan job mix formula (JMF) dengan tidak mengeyampingkan toleransi yang dikeluarkan oleh Direktorat Jenderal Binamarga yakni Spesifikasi Umum 2010 Revisi 3 (tiga) yakni sebesar \pm $0,3 \%$ dari berat campuran.

\section{Jumlah Sampel}

Penelitian ini dilakukan dilapangan dan dilaboratorium. Benda uji pertama diambil pada instalasi pencampur aspal (asphalt mixing plant), benda uji kedua diambil saat sampai dilapangan (dalam dump truck), benda uji ketiga diambil pada mesin penghampar (dibelakang asphalt finisher), dan benda uji keempat diambil setelah dilakukan pemadatan oleh mesin pemadat (hasil core). Setelah pengambilan benda uji tersebut, benda uji tersebut dibagi menjadi 6 buah sampel. Berat untuk setiap sampel minimal sebesar 1100 gram.

\section{Bagan Alir Penelitian}

Penelitian ini dimulai dengan membaca bukubuku referensi dan mencari data dari internet yang berhubungan dengan masalah penelitian, juga dari beberapa nara sumber. Langkah selanjutnya adalah mengumpulkan data di lapangan untuk pengambilan sampel ekstraksi dan selanjutnya sampel tersebut diuji di laboratorium. Langkah-langkah penelitian tergambar pada bagan alir dan dilihat pada gambar 1 .

\section{Ektraksi Kadar Aspal}




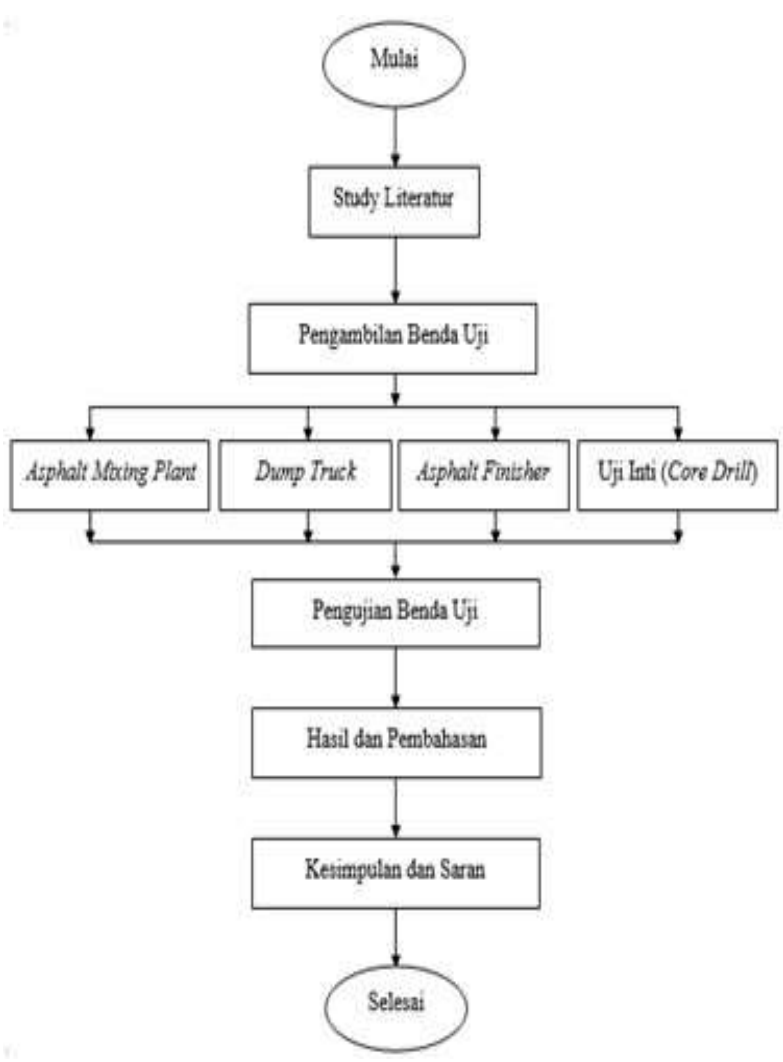

Gambar 1. Diagram alir penelitian

\section{HASIL DAN PEMBAHASAN}

Hasil pengujian ekstraksi yang diambil di asphalt mixing plant (AMP), di dump truck, di asphalt finisher dan uji inti (core) dapat dilihat pada tabel 2 sampai dengan tabel 5 dan gambar 2 sampai gambar 5. Dari hasil pengujian tersebut dapat dilihat penurunan kadar aspal sehingga dapat dirumuskan kadar aspal (KA) yakni sebagai berikut:

KA Job Mix Formula (AMP) > KA Dump Truck > KA Asphalt Finisher $>$ KA Core

Rata-rata: $5,60 \%>5,59 \%>5,58 \%>5,49 \%$

\begin{tabular}{|c|c|c|c|c|c|c|}
\hline No & Benda LfF & $\begin{array}{c}\text { Kadar aspal Hasi } \\
\text { Distralksi }(\%)\end{array}$ & $\begin{array}{c}\text { Kadar aspal } \\
\text { DIF }(\%)\end{array}$ & Deviasi (46) & $\begin{array}{l}\text { Toleransi } \\
\text { Spek: (9i) }\end{array}$ & Keterangan \\
\hline 1 & Sample -1 & 5,61 & 5,60 & $-0,01$ & $=0.3$ & Mememuhi \\
\hline 2 & Sample -2 & 5,60 & 5,60 & 0,00 & $=03$ & Memenuhi \\
\hline 3 & Sample -3 & 5,59 & 5,60 & 0,01 & $=03$ & Mememuhi \\
\hline 4 & Sample 4 & 5,60 & 5,60 & 0,000 & $=0.3$ & Mememuhi \\
\hline 5 & Sample -5 & 5,60 & 5,60 & 0,000 & $=03$ & Memenuhi \\
\hline 6 & Sample -6 & 5,59 & 5,60 & 0,01 & $=03$ & Memenuhi \\
\hline \multicolumn{2}{|c|}{ Rata-rata } & 5,60 & 5,60 & 0,00 & & \\
\hline
\end{tabular}

Tabel 2. Hasil pengujian AMP

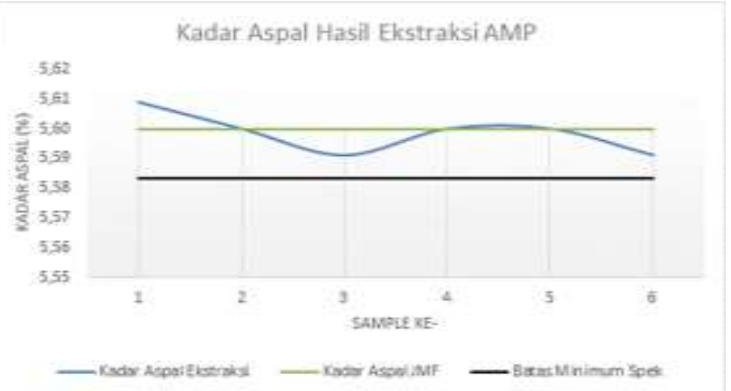

Gambar 2. Grafik pengujian AMP

\begin{tabular}{|c|c|c|c|c|c|c|}
\hline No & Benda LjI & $\begin{array}{c}\text { Kadar aspal Hasil } \\
\text { Eistraksi (\%) }\end{array}$ & $\begin{array}{c}\text { Kadar aspal } \\
\text { MI }(\%) \\
\end{array}$ & Deviasi (60) & $\begin{array}{l}\text { Toleransi } \\
\text { Spet: (\%) }\end{array}$ & Keterangen \\
\hline 1 & Semple -1 & 5,60 & 5,60 & 0,00 & $=03$ & Mememuhi \\
\hline 2 & Semple -2 & 5,60 & 5,60 & 0,00 & $=03$ & Mememuhi \\
\hline 3 & Semple -3 & 5,59 & 5,600 & 0,01 & $=03$ & Memenuhi \\
\hline 4 & Semple 4 & 5,59 & 5,600 & 0,01 & $=03$ & Mememuhi \\
\hline 5 & Semple -5 & 5,59 & 5,600 & 0,01 & $=03$ & Memenuhi \\
\hline 6 & Semple - 6 & 5,59 & 5,60 & 0,01 & $=03$ & Memenuhi \\
\hline & ate-rata & 5,59 & 5,60 & 0,01 & & \\
\hline
\end{tabular}

Tabel 3. Hasil pengujian dump truck

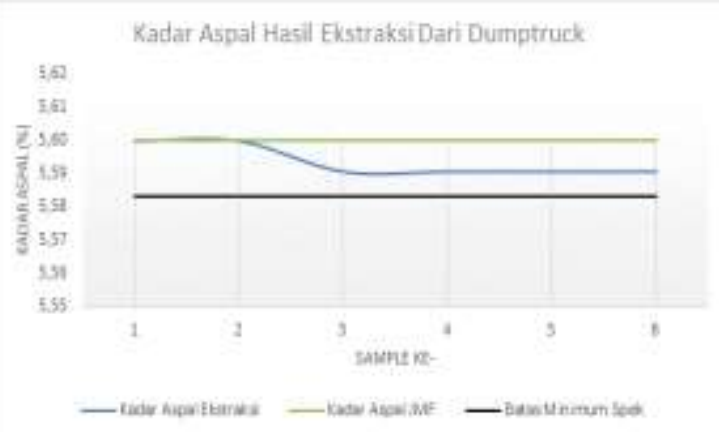

Gambar 3. Grafik pengujian dump truck

\begin{tabular}{|c|c|c|c|c|c|c|}
\hline No & Benda Uj & $\begin{array}{c}\text { Kadar aspal Hasil } \\
\text { Distraksi }(\%)\end{array}$ & $\begin{array}{c}\text { Kadar aspal } \\
\text { DIF (39) }\end{array}$ & Deviasi (10) & $\begin{array}{l}\text { Tolerensi } \\
\text { Spek: }(\%)\end{array}$ & Keterangen \\
\hline 1 & Sample -1 & 5,59 & 5,60 & 0,01 & $=0.3$ & Mememuhi \\
\hline 2 & Sample -2 & 5,58 & 5,60 & 0,02 & $=0.3$ & Memenuhi \\
\hline 3 & Sample -3 & 5,58 & 5,60 & 0,02 & $=0.3$ & Mememuhi \\
\hline 4 & Sample 4 & 5,58 & 5,60 & 0,02 & $=03$ & Mememuhi \\
\hline 5 & Sample -5 & 5,59 & 5,60 & 0,01 & $=03$ & Memenuhi \\
\hline 6 & Semple -6 & 5,58 & 5,60 & 0,02 & $=03$ & Mememuhi \\
\hline \multicolumn{2}{|c|}{ Rata-rata } & 5,58 & 5,60 & 0,02 & & \\
\hline
\end{tabular}

Tabel 4. Hasil pengujian asphalt finisher

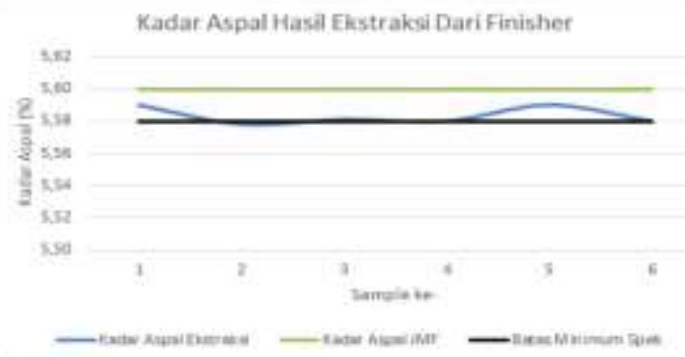

Gambar 3. Grafik pengujian asphalt finisher 


\begin{tabular}{|c|c|c|c|c|c|c|}
\hline $\mathrm{Na}$ & Bendat5 & $\begin{array}{c}\text { Kolat aspal Fana } \\
\text { Patrakaidey }\end{array}$ & $\begin{array}{l}\text { Katar apal } \\
\text { MAf og }\end{array}$ & Devisu (6) & $\begin{array}{l}\text { Toletienti } \\
\text { Spek.jol }\end{array}$ & Koterangan \\
\hline 1 & Sangle - I & 2.51 & 5.60 & 0.00 & $=03$ & $\begin{array}{c}\text { Tilaik } \\
\text { Marnmmihi }\end{array}$ \\
\hline 2 & Sangle - 2 & 2,49 & 5,00 & 0.11 & -03 & $\begin{array}{c}\text { Tidak } \\
\text { Mannemuhi }\end{array}$ \\
\hline 3 & Sungle -3 & $9,47$. & 5.00 & 0,13 & $=0.3$ & $\begin{array}{c}\text { Tridak } \\
\text { Menenuhi }\end{array}$ \\
\hline 4 & Sarpete th & 5,40 & 5.60 & 0,11 & $=0.3$ & $\begin{array}{c}\text { Trdak } \\
\text { Menenwhi }\end{array}$ \\
\hline 5 & Sangle- 5 & 5,47 & 5,00 & 0,13 & $=03$ & $\begin{array}{c}\text { Tidak } \\
\text { Menenulu }\end{array}$ \\
\hline${ }^{\circ}$ & Sarpie-s. & $\$, 50$ & 5,60 & 0.10 & $=0.3$ & $\begin{array}{c}\text { Tidak } \\
\text { Manumulu }\end{array}$ \\
\hline & atanata & $\$ .40$ & 5.60 & 0.11 & & \\
\hline
\end{tabular}

Tabel 5. Hasil pengujian uji inti (core)

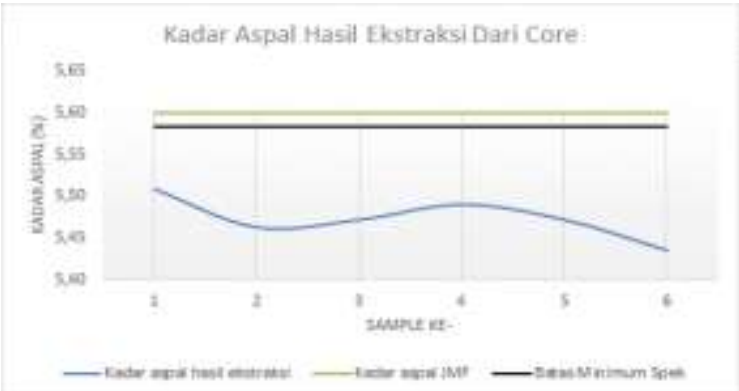

Gambar 4. Grafik pengujian uji inti (core)

Hasil pengujian ekstraksi kadar aspal pada masingmasing benda uji dapat dilihat bahwa kadar aspal uji inti (core) lebih kecil dari kadar asphalt finisher, kadar aspal dump truck dan kadar aspal asphalt mixing plant (AMP). Kadar aspal AMP lebih besar dari kadar aspal dump truck, asphalt finisher, dan core disebabkan oleh sampel aspal yang di ambil pada AMP merupakan aspal gembur yang baru selesai diolah, sehingga waktu dilakukan ekstraksi pengaruh kehilangan kadar aspal lebih kecil karena kemungkinan melekat pada dinding AMP sangat kecil. Sedangkan saat didalam dump truck pada saat pengangkutan terindikasi material melekat pada dinding dump truck dan terpal penutup dump truck dan penyerapan agregat kedalam pori agregat. Sedangkan saat berada di asphalt finisher faktor melekat pada katup asphalt finisher, setrika asphalt finisher, dan penyerapan agregat kedalam pori agregat. Sedangkan pada uji inti terdapatnya material yang terbelah oleh mesin core drill, sehingga kadar aspal terindikasi terbagi dikarenakan agregat yang terbelah.

\section{KESIMPULAN DAN SARAN}

\section{Kesimpulan}

Dari penelitian dan pembahasan mengenai kadar aspal buton hasil ekstraksi penghamparan campuran Laston Lapis Antara (AC-BC) dengan Job Mix Formula (JMF), dapat diambil kesimpulan sebagai berikut:

1. Setelah dilakukan penelitian didapat persentase kadar aspal buton pada AMP sebesar 5,6\%, pada dump truck sebesar 5,59\%, pada asphalt finisher $5,58 \%$, dan pada uji inti (core) sebesar 5,49\%, maka dari itu disimpulkan penurunan kadar aspal buton tersebut sebesar 0\% di AMP, sebesar 0,081\% pada dump truck, sebesar 0,274\% pada asphalt finisher, dan sebesar $1,949 \%$ pada uji inti (core).

2. Dari hasil keseluruhan percobaan penelitian kadar aspal buton rata-rata mengalami deviasi sebesar $0,3 \%$ terhadap job mix formula (JMF).

3. Setelah dilakukan penelitian terhadap hasil ekstraksi uji inti (core) didapat juga kesimpulan bahwa hasil ekstraksi jauh dari ambang batas minimum toleransi campuran. Maka dari itu penelitian ini juga mendukung pernyataan spesifikasi yang menyebutkan uji inti (core) tidak boleh digunakan untuk pengujian ekstraksi.

\section{Saran}

Dari penelitian dan pembahasan mengenai kadar aspal buton hasil ekstraksi penghamparan campuran Laston Lapis Antara (AC-BC) dengan Job Mix Formula (JMF) saya selaku penulis memberikan saran yakni sebagai berikut:

1. Diharapkan ada peneliti selanjutnya menggunakan pelarut yang memiliki Oktan yang lebih tinggi agar hasil ekstraksi lebih teliti.

2. Disarankan untuk peneliti selanjutnya untuk mengkaji Stability (pengujian Marshall Test) Terhadap campuran aspal buton untuk campuran laston lapis antara (AC-BC).

3. Terkait dengan hasil penelitian disarankan kepada pihak yang terkait bahwasanya Spesifikasi Umum Bina Marga 2010 Revisi 3 (dua) ini bisa diterima untuk mata pembayaran dengan perbandingan 4 (empat) nilai hasil ekstraksi, yakni pada Asphalt Mixing Plant (AMP), alat mobilisasi campuran aspal (Dump Truck), Asphalt Finisher, Uji Inti (core).

\section{DAFTAR PUSTAKA}

Annas LP. 2013. Ekstraksi Asbuton Butir Dengan Metode Asbuton Emulsi Menggunakan Pengemulsi Texapon Ditinjau Dari Konsentrasi Air Dan Waktu Ekstraksi. Surakarta: e-JurnalMatrik Teknik Sipil Vol. 1 No. 4.

Badan Standarisasi Nasional, Metode Pengujian Kadar Aspal Dari Capuran Beraspal Dengan Cara Sentrifus. SNI-03-6894-2002 Jakarta: BSN.

Direktorat Jenderal Binamarga. 2010. Spesifikasi Umum Binamarga 2010 Revisi 3. Kementerian Pekerjaan Umum Direktorat Jenderal Binamarga, Jakarta, 2010.

Direktorat Jenderal Binamarga. 2006. Spesifikasi Umum Binamarga 2006. Kementerian Pekerjaan Umum Direktorat Jenderal Binamarga, Jakarta, 2006. 
Soehardi F. 2014. Kajian Perbandingan Kadar Aspal Hasil Ekstraksi Campuran ACWC Gradasi Kasar Dengan Cairan Ekstraksi Menggunakan Bensin (Tesis). Pekanbaru: Program Magister Teknik Sipil Universitas Islam Riau.

Hadihardaja J. 1997. Rekayasa Jalan Raya. Jakarta: Gunadarma.

Suryadharma H. 2008. Rekayasa Jalan Raya. Yogyakarta: Universitas Atmajaya.

Sumantoro I. 2018. Aspal Buton Menjawab Tantangan Zaman.Http://indonesiana.tempo.co/read/121574/20 18/01/11/roomances.info/login. (20 mei 2018).

Departemen Pekerjaan Umum. Peraturan Menteri Pekerjaan Umum Nomor: 39/PRT/M/2006 Tentang Petunjuk Teknis.

Putri LD. 2015.Kajian Kadar Aspal Hasil Ektraksi Penghamparan dan mix design pada campuran Asphalt Concrete Wearing Course (AC-WC) GradasiHalus (Tesis). Pekanbaru: Program Magister Teknik SipilUniversitas Islam Riau.

Sukirman S. 2003. Beton Aspal Campuran Panas. Jakarta: Granit.

Sarwono D. 2013. Ekstraksi Asbuton Menggunakan Metode Asbuton Emulsi (269 M). Surakarta: Konferensi Nasional Teknik Sipil 7 Universitas Sebelas Maret.

Tenriajeng AT. 2002. Rekayasa Jalan Raya 2. Jakarta: Gunadarma.

Wignall A. 2003. Proyek Jalan Teori dan Praktek. Jakarta: Erlangga. 